\title{
The tumor-suppressive microRNA-23b/27b cluster regulates the $M E T$ oncogene in oral squamous cell carcinoma
}

\author{
ICHIRO FUKUMOTO $^{1,2}$, KEIICHI KOSHIZUKA ${ }^{1,2}$, TOYOYUKI HANAZAWA ${ }^{2}$, NAOKO KIKKAWA ${ }^{2}$, \\ RYOSUKE MATSUSHITA $^{3}$, AKIRA KUROZUMI ${ }^{1}$, MAYUKO KATO $^{1}$, \\ ATSUSHI OKATO $^{1}$, YOSHITAKA OKAMOTO ${ }^{2}$ and NAOHIKO SEKI ${ }^{1}$
}

\author{
Departments of ${ }^{1}$ Functional Genomics and ${ }^{2}$ Otorhinolaryngology/Head and Neck Surgery, \\ Chiba University Graduate School of Medicine, Chuo-ku, Chiba 260-8670; \\ ${ }^{3}$ Department of Urology, Graduate School of Medical and Dental Sciences, \\ Kagoshima University, Kagoshima-shi, Kagoshima 890-8520, Japan
}

Received April 13,2016; Accepted June 6, 2016

DOI: 10.3892/ijo.2016.3602

\begin{abstract}
Our recent studies of microRNA (miRNA) expression signatures in human cancers revealed that two clustered miRNAs, microRNA-23b (miR-23b) and microRNA-27b $(m i R-27 b)$, were significantly reduced in cancer tissues. Few reports have provided functional analyses of these clustered miRNAs in oral squamous cell carcinoma (OSCC). The aim of this study was to investigate the functional significance of $m i R-23 b$ and $m i R-27 b$ in OSCC and to identify novel $m i R-23 b / 27 b$-mediated cancer pathways and target genes involved in OSCC oncogenesis and metastasis. Expression levels of $m i R-23 b$ and $m i R-27 b$ were significantly reduced in OSCC specimens. Restoration of $m i R-23 b$ or $m i R-27 b$ in cancer cells revealed that both miRNAs significantly inhibited cancer cell migration and invasion. Our in silico analyses and luciferase reporter assays showed that the receptor tyrosine kinase $M E T$, was directly regulated by these miRNAs. Moreover, downregulating the $M E T$ gene by use of siRNA significantly inhibited cell migration and invasion by OSCC cells. The identification of novel molecular pathways regulated by $m i R-23 b$ and $m i R-27 b$ may lead to a better understanding of the oncogenesis and metastasis of this disease.
\end{abstract}

\section{Introduction}

Head and neck squamous cell carcinoma (HNSCC) is the sixth most common cancer in the world, and it consists of a heterogeneous group of malignancies arising from the oral cavity,

Correspondence to: Dr Naohiko Seki, Department of Functional Genomics, Chiba University Graduate School of Medicine, 1-8-1 Inohana, Chuo-ku, Chiba 260-8670, Japan

E-mail: naoseki@faculty.chiba-u.jp

Key words: microRNA, miR-23b, miR-27b, oral squamous cell carcinoma, $M E T$ paranasal sinus, pharynx, larynx and salivary glands (1). Most of oral squamous cell carcinoma (OSCC) occurs from oral cavity (accounts for $>95 \%$ ) and is the most common type of HNSCC (2). Despite recent advances in various treatment modalities, including surgery, radiotherapy, chemotherapy and molecularly targeted therapy, the survival rate of patients with OSCC has not markedly improved (5-year survival is $<50 \%$ ) due to the high rate of locoregional recurrence and distinct metastasis (3). We suggest that it would be possible to significantly improve diagnosis, therapy, and prevention of OSCC through a better understanding of the molecular oncogenic processes and metastatic pathways underlying the disease. We further suggest that this could be achieved through the use of current genome-based approaches.

The discovery of microRNA (miRNA) in the human genome provided new directions in cancer study. miRNAs are endogenous small non-coding RNAs (19-22 bases long) that regulate protein-coding/non protein-coding gene expression by repressing translation or degradation of RNA transcripts in a sequence-specific manner (4). A growing body of studies have shown that miRNAs are aberrantly expressed in many human cancers. Thus, they act pivotal roles in the initiation, progression and metastasis of such cancers (5). Moreover, normal RNA networks can be disrupted by the aberrant expression of tumor-suppressive or oncogenic miRNAs in cancer cells. Therefore, identifying aberrantly expressed miRNAs is an important first step toward understanding miRNA-mediated RNA networks.

Based on this proposal, we have constructed miRNA expression signatures through genetic analysis of hypopharyngeal-SCC, maxillary sinus-SCC and OSCC clinical specimens (6-9). Using these miRNA expression signatures, we have identified molecular pathways in HNSCC that are mediated by aberrantly expressed miRNAs. For example, downregulation of tumor-suppressive $m i R$ - 375 inhibited cancer cell apoptosis through dysregulation of $A E G-1 / M T D H$ in HNSCC cells (10). Moreover, downregulation of $m i R-874$ is a frequent event in HNSCC and $m i R-874$ acted as a tumor suppressor that directly targets $H D A C 1$ (11). More recently, we found that $m i R-26 a$ and 
$m i R-26 b$ function as tumor suppressors through regulating of TMEM184B based on the OSCC signature (9).

Our miRNA expression signatures of human cancers, including OSCC, revealed that clustered miRNAs, $m i R-23 b$ and $m i R-27 b$ were frequently downregulated in several types of cancer tissues (9,12-14). Several studies showed that these miRNAs act as tumor suppressive miRNAs through their targeting of oncogenic genes (15-17). Up to now, few reports have provided functional analyses of these clustered miRNAs in OSCC. The aims of the study were to investigate the functional roles of $m i R-23 b$ and $m i R-27 b$ in OSCC and to identify novel $m i R-23 b / 27 b$-mediated cancer pathways and target genes involved in OSCC oncogenesis and metastasis. We expect that this analysis will provide novel insights into the pivotal molecular mechanisms of OSCC oncogenesis and metastasis. This new knowledge will facilitate the development of therapeutic strategies for the treatment of the disease.

\section{Materials and methods}

Clinical specimens in patients with OSCC and cell lines. A total of 37 pairs of cancer tissues and corresponding normal epithelial tissues were obtained from patients with OSCC at Chiba University Hospital from 2008 to 2013. The patients were classified according to the 2002 Union for International Cancer Control (UICC) staging criteria before treatment. Prior written informed consent and approval were obtained from all patients. The patients' backgrounds and clinicopathological characteristics are shown in Table I. The following human OSCC cell lines were used: SAS (derived from a primary tongue SCC) and HSC3 (derived from a lymph node metastasis of tongue SCC).

RNA isolation. Tissues were immersed in RNAlater (Ambion, Austin, TX, USA), and stored at $4^{\circ} \mathrm{C}$ until RNA was extracted. Total RNA was isolated using TRIzol reagent according to the manufacturer's instructions.

Quantitative of miRNAs and messenger RNA by real-time $R T-P C R$. The procedure for PCR quantification was described previously (6-11). The expression levels of $m i R-23 b$ (assay ID: 000400) and $m i R-27 b$ (assay ID: 000409) were analyzed by TaqMan quantitative real-time PCR and normalized to RNU48 (assay ID: 001006). TaqMan probes and primers for $\operatorname{MET}(\mathrm{P} / \mathrm{N}$ : Hs01565584_m1), GUSB (P/N: Hs 00939627_ml) and $G A P D H(\mathrm{P} / \mathrm{N}$ : Hs02758991_g1) as an internal control were obtained from Applied Biosystems.

Function assays by miRNA and small-interfering RNA transfection. The following miRNAs mimics were used in this study: mirVana miRNA mimic for $h s a-m i R-23 b$ (product ID: PM10711) and hsa-miR-27b (product ID: PM10750). The transfection procedures and transfection efficiencies of miRNA for SAS and HSC3 cells were reported in previous studies $(6-9,11,15,18)$. To investigate the functional significance of $m i R-23 b, m i R-27 b$ and $s i-M E T$, we performed cell proliferation, migration and invasion assays using OSCC cell lines. The experimental procedures were described in previous studies $(8,9,15,18)$.
Identification of target genes regulated by miR-23b, miR-27b by using genome-wide gene expression and in silico analysis. The miRNA public database (TargetScan) was used for in silico identification of candidate target genes that contained $m i R-23 b$ and $m i R-27 b$ binding sites in their 3'-untranslated region. These genes were then categorized into KEGG pathways using the GeneCodis program (http://genecodis.dacya. ucm.es). To identify upregulated genes in OSCC, we analyzed a publicly available gene expression data set in GEO (accession no. GSE6631).

Western blotting. Cells were harvested $72 \mathrm{~h}$ after transfection and lysates were prepared. From each lysate, an aliquot containing $20 \mu \mathrm{g}$ of protein was separated on Mini-PROTEAN TGX Gels (Bio-Rad, Hercules, CA, USA) and transferred to PVDF membranes. Immunoblotting was performed with rabbit anti-MET antibodies (1:1,000); mouse anti-GAPDH antibodies $(1: 4,000)$ were used as an internal loading control. The experimental procedures were performed as described in our previous studies $(6-9,11,15,18)$.

Immunohistochemistry. Two OSCC clinical specimens were immunostained following the manufacturer's protocol with the Ultra-Vision detection system (Thermo Scientific, Fremont, CA, USA). Primary rabbit polyclonal antibodies against MET were diluted 1:300. The slides were treated with biotinylated goat antibodies.

Plasmid construction and dual-luciferase reporter assays. The partial wild-type sequence of the MET 3'-untranslated region or those with mutated $m i R-23 b / m i R-27 b$ target sites were inserted between the XhoI-PmeI restriction sites in the 3'-UTR of the hRluc gene in the psiDHECK-2 vector (C8021; Promega, Madison, WI, USA). The procedure for the dual-luciferase reporter assay was described previously $(6-9,11,15,18)$.

Statistical analysis. The relationships between two groups and numerical values obtained by real-time RT-qPCR were analyzed using Mann-Whitney U tests. Spearman's rank test was used to evaluate the correlation between the expression levels of $m i R-23 b, m i R-27 b$ and $M E T$ mRNA. The relationships among more than three variables and numerical values were analyzed using the Mann-Whitney U test after Bonferroni adjustment. All analyses were performed using Expert Stat View (version 5, SAS Institute Inc., Cary, NC, USA).

\section{Results}

Expression levels of $\mathrm{miR}-23 \mathrm{~b}$ and $\mathrm{miR}-27 \mathrm{~b}$ in OSCC tissues and cell lines. We evaluated the expression levels of the clustered miRNAs in 37 OSCC clinical specimens and two cell lines. The expression levels of $m i R-23 b$ and $m i R-27 b$ were significantly lower in tumor tissues and cell lines than in corresponding normal tissues (Fig. 1A and B). Spearman's rank test showed a positive correlation between the expression levels of $m i R-23 b$ and $m i R-27 b$ (Fig. 1C).

Gain-of-function assay of miR-23b and miR-27b in OSCC cell lines: effects on cell proliferation, migration and invasion. 
Table I. Clinical features of 37 OSCC patients.

\begin{tabular}{|c|c|c|c|c|c|c|c|c|}
\hline No. & Age & Sex & Location & $\mathrm{T}$ & $\mathrm{N}$ & M & Stage & Differentiation \\
\hline 1 & 66 & $\mathrm{M}$ & Tongue & 2 & 0 & 0 & II & Moderate \\
\hline 2 & 65 & $\mathrm{M}$ & Oral floor & $4 a$ & 1 & 0 & IVA & Moderate \\
\hline 3 & 67 & $\mathrm{M}$ & Tongue & $4 a$ & $2 \mathrm{c}$ & 0 & IVA & Moderate \\
\hline 4 & 36 & $\mathrm{~F}$ & Tongue & 3 & 1 & 0 & III & Moderate \\
\hline 5 & 73 & $\mathrm{M}$ & Tongue & 3 & $2 b$ & 0 & IVA & Poor \\
\hline 6 & 63 & $\mathrm{~F}$ & Oral floor & 2 & $2 b$ & 0 & IVA & Basaloid SCC \\
\hline 7 & 77 & $\mathrm{M}$ & Gum & 2 & 0 & 0 & II & Moderate \\
\hline 8 & 68 & $\mathrm{M}$ & Tongue & 2 & 0 & 0 & II & Well \\
\hline 9 & 76 & $\mathrm{~F}$ & Tongue & 1 & 0 & 0 & I & Well \\
\hline 10 & 69 & $\mathrm{M}$ & Tongue & 1 & 0 & 0 & I & Well \\
\hline 11 & 73 & $\mathrm{~F}$ & Tongue & 1 & 0 & 0 & I & Well \\
\hline 12 & 64 & $\mathrm{M}$ & Tongue & 1 & 0 & 0 & I & Well \\
\hline 13 & 64 & $\mathrm{M}$ & Tongue & 1 & 0 & 0 & I & Well \\
\hline 14 & 82 & $\mathrm{M}$ & Oral floor & 1 & 0 & 0 & I & Well \\
\hline 15 & 67 & $\mathrm{M}$ & Oral floor & $4 a$ & $2 b$ & 0 & IVA & Well \\
\hline 16 & 67 & $\mathrm{M}$ & Tongue & 3 & 0 & 0 & III & Moderate \\
\hline 17 & 64 & $\mathrm{M}$ & Tongue & 3 & $2 b$ & 0 & IVA & Moderate \\
\hline 18 & 59 & $\mathrm{M}$ & Tongue & 1 & $2 \mathrm{a}$ & 0 & IVA & Moderate \\
\hline 19 & 47 & $\mathrm{M}$ & Oral floor & 1 & 0 & 0 & I & Moderate \\
\hline 20 & 67 & $\mathrm{M}$ & Tongue & 2 & 0 & 0 & II & Poor-moderate \\
\hline 21 & 70 & $\mathrm{M}$ & Tongue & 1 & 0 & 0 & I & Well \\
\hline 22 & 38 & M & Tongue & 1 & 0 & 0 & I & Well \\
\hline 23 & 70 & $\mathrm{M}$ & Tongue, oral floor & 2 & 0 & 0 & II & Well \\
\hline 24 & 51 & M & Tongue & 1 & 0 & 0 & I & Well \\
\hline 25 & 81 & $\mathrm{M}$ & Tongue & is & 0 & 0 & 0 & Extremely well \\
\hline 26 & 34 & $\mathrm{~F}$ & Tongue & 1 & 0 & 0 & I & Poor \\
\hline 27 & 42 & $\mathrm{M}$ & Gum & $4 a$ & 0 & 0 & IVA & Moderate \\
\hline 28 & 70 & $\mathrm{M}$ & Tongue & 1 & 0 & 0 & I & Moderate \\
\hline 29 & 71 & $\mathrm{M}$ & Tongue & 1 & 0 & 0 & I & Well \\
\hline 30 & 60 & $\mathrm{~F}$ & Tongue & 2 & I & 0 & III & Well \\
\hline 31 & 77 & $\mathrm{M}$ & Tongue & 2 & $2 b$ & 0 & IVA & Poorly \\
\hline 32 & 64 & $\mathrm{~F}$ & Oral floor & $4 a$ & $2 c$ & 0 & IVA & Moderate \\
\hline 33 & 68 & $\mathrm{M}$ & Tongue & 1 & 0 & 0 & I & Well \\
\hline 34 & 39 & $\mathrm{M}$ & Tongue & $4 a$ & 0 & 0 & IVA & Well \\
\hline 35 & 29 & $\mathrm{~F}$ & Tongue & 1 & 0 & 0 & I & Poorly \\
\hline 36 & 71 & M & Buccal mucosa & 2 & 1 & 0 & III & Poorly \\
\hline 37 & 39 & $\mathrm{M}$ & Tongue & $4 a$ & 0 & 0 & IVA & Moderate \\
\hline
\end{tabular}

The functional significance of $m i R-23 b$ and $m i R-27 b$ were investigated using miRNA transfection of OSCC cell lines. XTT assays demonstrated that SAS cell proliferation was significantly inhibited in $m i R$ - $23 b$ - and $m i R$-27b-transfectants compared with the mock or miR-control transfected SAS cells. On the other hand, proliferation was inhibited only in $m i R-27 b$ transfectant in HSC3 (Fig. 1D). Migration and invasion assays demonstrated that cell migration and invasion activity were significantly inhibited in $m i R-23 b$ and $m i R-27 b$ transfectants compared with the mock or miR-control transfectants in OSCC cell lines (Fig. 1E and F).

Selection of genes targeted by miR-23b and miR-27b in OSCC. To identify genes targeted by $m i R-23 b$ and $m i R-27 b$, we use in silico analyses and genome-wide expression analyses. Our strategy for identification of target genes is shown in Fig. 2. 

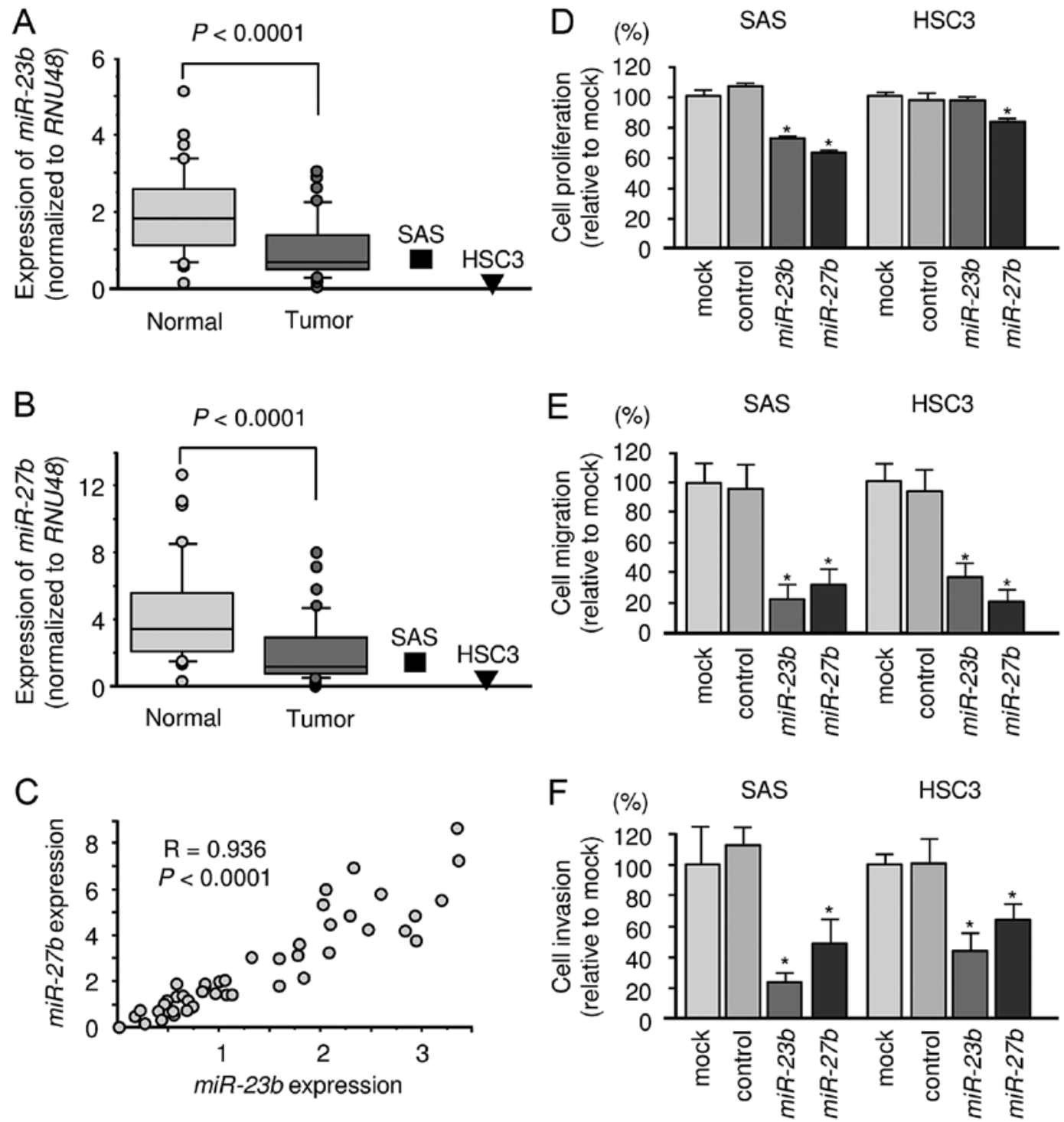

Figure 1. Expression levels of $m i R-23 b$ and $m i R-27 b$ and functional significance of $m i R-23 b$ and $m i R-27 b$ in OSCC cell lines. (A and B) Expression levels of $m i R-23 b$ and $m i R-27 b$ in OSCC clinical specimens and cell lines. RNU48 was used for internal control. (C) Correlations between the expression levels of $m i R-23 b$ and $m i R-27 b$ in OSCC clinical specimens. (D) Cell proliferation was determined with the XTT assay $72 \mathrm{~h}$ after transfection with $m i R-23 b$ or $m i R-27 b$. (E) Cell migration was assessed with the migration assay $48 \mathrm{~h}$ after transfection with $m i R-23 b$ or $m i R-27 b$. (F) Cell invasion was characterized with an invasion assay $48 \mathrm{~h}$ after transfection with $m i R-23 b$ or $m i R-27 b .{ }^{*} \mathrm{P}<0.0001$

First, we screened putative candidate target genes using the TargetScan database and identified 229 potential targets. These genes were classified into KEGG pathways using GeneCodis analysis and four pathways and 18 genes were identified as significantly enriched pathways (Table IIA) and genes (Table IIB-E). The gene set was then analyzed with a publicly available gene expression data set in GEO (accession no. GSE6631). In this group of genes, we focused on the hepatocyte growth factor receptor (MET) because it was the most significantly upregulated in HNSCC (Fig. 3).

Expression of MET in OSCC clinical specimens and cell lines. We investigated the expression levels of MET in 37 OSCC clinical specimens and cell lines. First, qRT-PCR revealed that $M E T$ was significantly upregulated in cancer tissues and cell lines compared with normal tissues (Fig. 4A). Spearman's rank test showed negative correlations between the expression levels of miR-23b/miR-27b and MET (Fig. 4B and C). Next, immunohistochemistry revealed that MET was strongly expressed in cancer tissues, while low expression was observed in normal tissues (Fig. 4D and E).

Direct regulation of MET gene by $\mathrm{miR}-23 \mathrm{~b}$ and $\mathrm{miR}-27 \mathrm{~b}$ in OSCC cells. We investigated the expression levels of MET in OSCC cell lines. We performed quantitative real-time RT-PCR and western blotting in OSCC cell lines to investigate whether restoration of $m i R-23 b$ or $m i R-27 b$ altered $M E T$ gene and protein expression. mRNA expression levels of $M E T$ were significantly repressed in $m i R-23 b$ and $m i R-27 b$ transfectants compared with mock or miR-control transfectant in OSCC cell lines (Fig. 5A). Protein expression levels of MET were repressed in $m i R-23 b$ and $m i R-27 b$ transfectants compared 
Table II. The KEGG pathways.

A, Significantly enriched KEGG pathway regulated by $m i R-23 b / 27 b$ cluster

\begin{tabular}{llc}
\hline $\begin{array}{l}\text { No. of } \\
\text { genes }\end{array}$ & \multicolumn{1}{c}{ Annotations } & P-value \\
\hline 10 & $\begin{array}{l}\text { (KEGG) 05200: Pathways in cancer } \\
\text { (KEGG) 04810: Regulation of actin }\end{array}$ & 0.0082 \\
7 & $\begin{array}{l}\text { cytoskeleton } \\
\text { (KEGG) 04010: MAPK signaling }\end{array}$ & 0.0235 \\
8 & $\begin{array}{l}\text { pathway } \\
\text { (KEGG) 05218: Melanoma }\end{array}$ & 0.0372 \\
\hline
\end{tabular}

$\mathrm{B}$, Pathway in cancer

\begin{tabular}{|c|c|c|}
\hline $\begin{array}{l}\text { Gene } \\
\text { symbol }\end{array}$ & Gene name & $\begin{array}{l}\text { HNSCC } \\
\log 2 \text { ratio }\end{array}$ \\
\hline$L A M C 2$ & Laminin, $\gamma 2$ & 2.33 \\
\hline$F G F 1$ & Fibroblast growth factor 1 (acidic) & 2.32 \\
\hline PTCH1 & Patched 1 & 2.24 \\
\hline FZD7 & Frizzled family receptor 7 & 2.18 \\
\hline PAX8 & Paired box 8 & 1.43 \\
\hline$F G F 12$ & Fibroblast growth factor 12 & 1.39 \\
\hline$R U N X 1$ & Runt-related transcription factor 1 & 1.27 \\
\hline$M E T$ & $\begin{array}{l}\text { Met proto-oncogene (hepatocyte } \\
\text { growth factor receptor) }\end{array}$ & 1.26 \\
\hline МАРК 10 & $\begin{array}{l}\text { Mitogen-activated protein } \\
\text { kinase } 10\end{array}$ & 1.22 \\
\hline$E G F R$ & Epidermal growth factor receptor & 1.15 \\
\hline \multicolumn{3}{|c|}{ C, Regulation of actin cytoskeleton } \\
\hline $\begin{array}{l}\text { Gene } \\
\text { symbol }\end{array}$ & Gene name & $\begin{array}{l}\text { HNSCC } \\
\log 2 \text { ratio }\end{array}$ \\
\hline$F G F 1$ & Fibroblast growth factor 1 (acidic) & 2.32 \\
\hline$F G F 12$ & Fibroblast growth factor 12 & 1.39 \\
\hline ARHGEF7 & $\begin{array}{l}\text { Rho guanine nucleotide exchange } \\
\text { factor (GEF) } 7\end{array}$ & 1.34 \\
\hline SSH1 & Slingshot homolog 1 (Drosophila) & 1.20 \\
\hline GNA13 & $\begin{array}{l}\text { Guanine nucleotide binding protein } \\
\text { (G protein), } \alpha 13\end{array}$ & 1.18 \\
\hline$E G F R$ & Epidermal growth factor receptor & 1.15 \\
\hline ENAH & Enabled homolog (Drosophila) & 1.09 \\
\hline
\end{tabular}

D, MAPK signaling pathway

\begin{tabular}{lc}
\hline Gene & Gene name \\
symbol & HNSCC \\
& $\log 2$ ratio \\
\hline
\end{tabular}

NTRK2 Neurotrophic tyrosine kinase, receptor, type 2

CACNAIB Calcium channel, voltagedependent, $\mathrm{N}$ type, $\alpha 1 \mathrm{~B}$ subunit
Table II. Continued.

\begin{tabular}{llc}
$\begin{array}{l}\text { Gene } \\
\text { symbol }\end{array}$ & \multicolumn{1}{c}{ Gene name } & $\begin{array}{c}\text { HNSCC } \\
\log 2 \text { ratio }\end{array}$ \\
\hline$F G F 1$ & Fibroblast growth factor 1 (acidic) & 2.32 \\
$F G F 12$ & Fibroblast growth factor 12 & 1.39 \\
MAP4K3 & Mitogen-activated protein kinase & 1.24 \\
& kinase kinase kinase 3 & \\
MAPK10 & Mitogen-activated protein kinase 10 & 1.22 \\
PRKX & Protein kinase, X-linked & 1.16 \\
EGFR & Epidermal growth factor receptor & 1.15 \\
\hline \multirow{2}{*}{ E, Melanoma } & & \\
\end{tabular}

Gene

Gene name

H average

symbol

\begin{tabular}{lll}
\hline FGF1 & Fibroblast growth factor 1 (acidic) & 2.32 \\
FGF12 & Fibroblast growth factor 12 & 1.39 \\
MET & Met proto-oncogene (hepatocyte & 1.26 \\
& growth factor receptor) & \\
EGFR & Epidermal growth factor receptor & 1.15
\end{tabular}

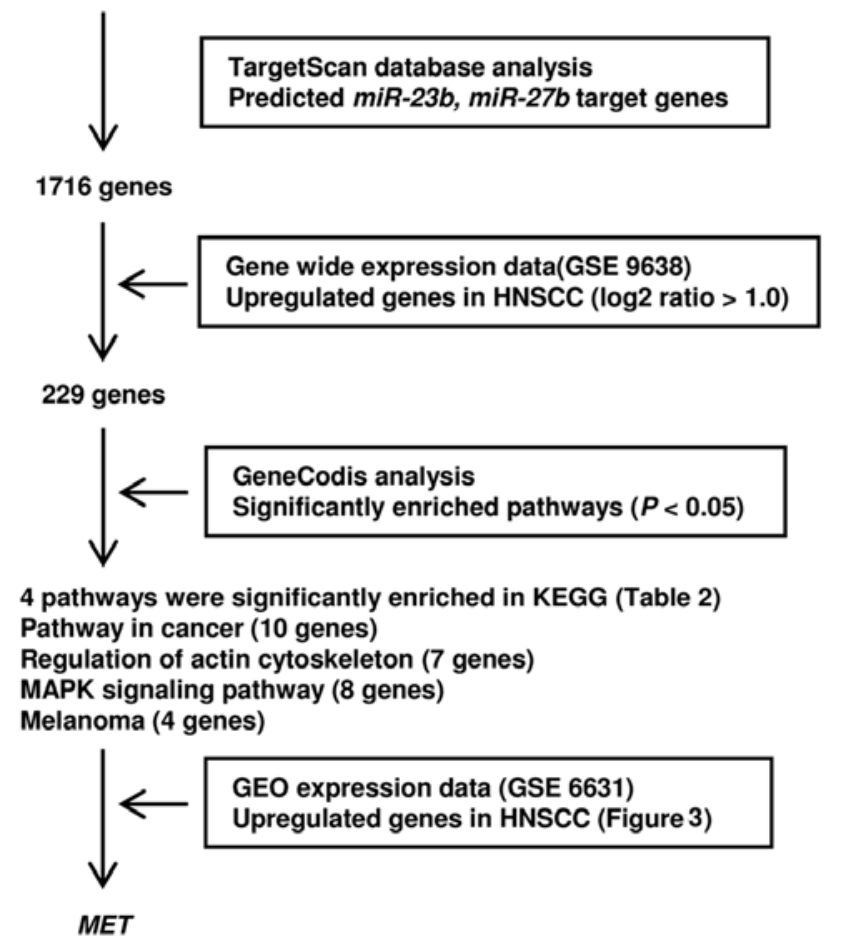

Figure 2. Selection for target genes regulated by $m i R-23 b / 27 b$ cluster. A total of 1,716 genes were identified as putative target genes containing binding sites for $m i R-23 b$ and $m i R-27 b$. Among these, 229 genes were upregulated in HNSCC (GSE9638). These genes were classified into KEGG pathways, and four pathways and 18 genes were identified as enriched pathways and genes.

with mock or miR-control in SAS. Although restoration of $m i R-27 b$ significantly suppressed MET protein expression, no significant downregulation of MET was observed in $m i R-23 b$ 

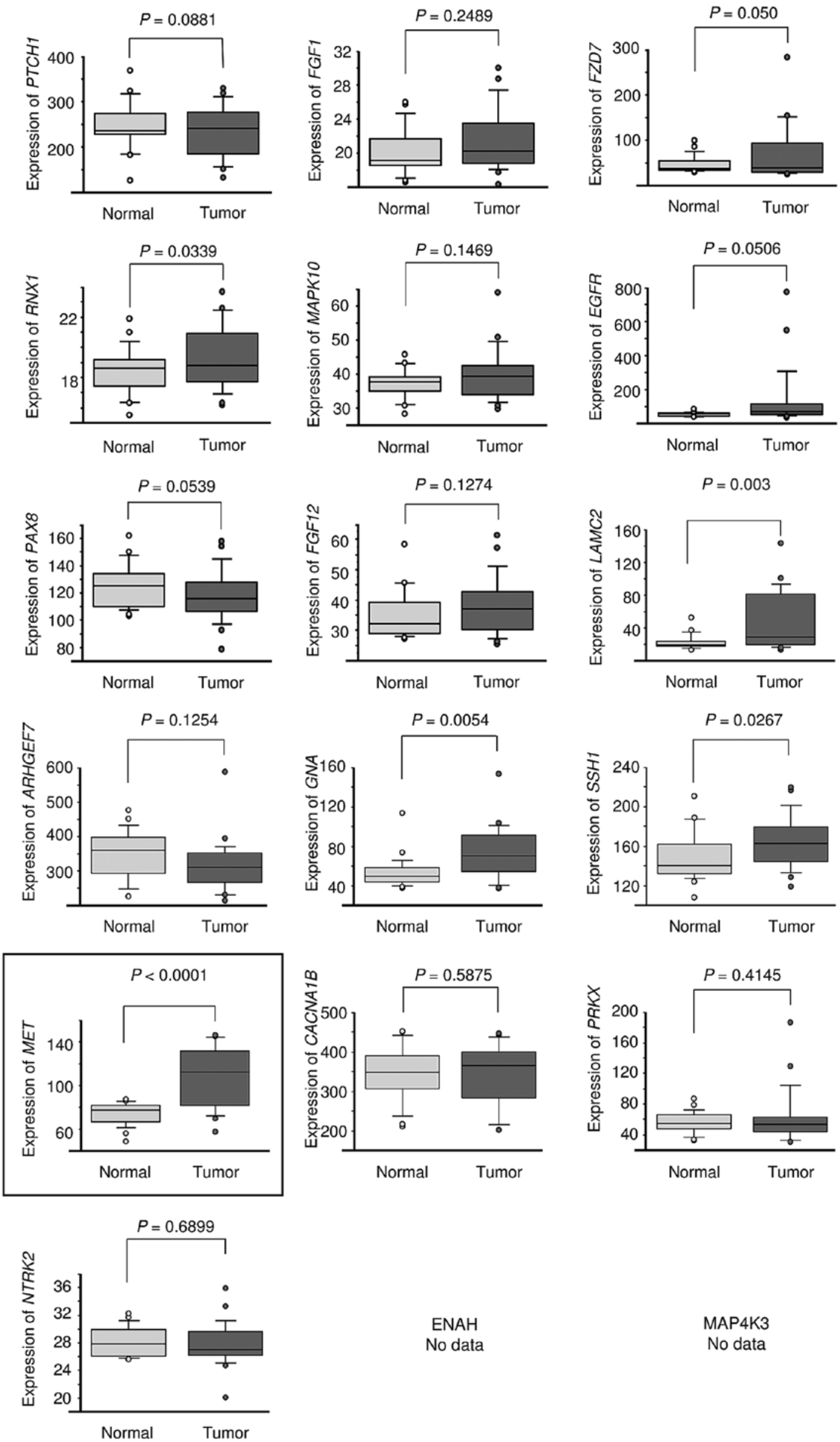

ENAH

MAP4K3

No data

No data

Figure 3. In silico analysis of HNSCC clinical specimens. The expression levels of putative target genes in HNSCC clinical specimens were investigated by GEO expression database (accession no. GSE6631). 
A
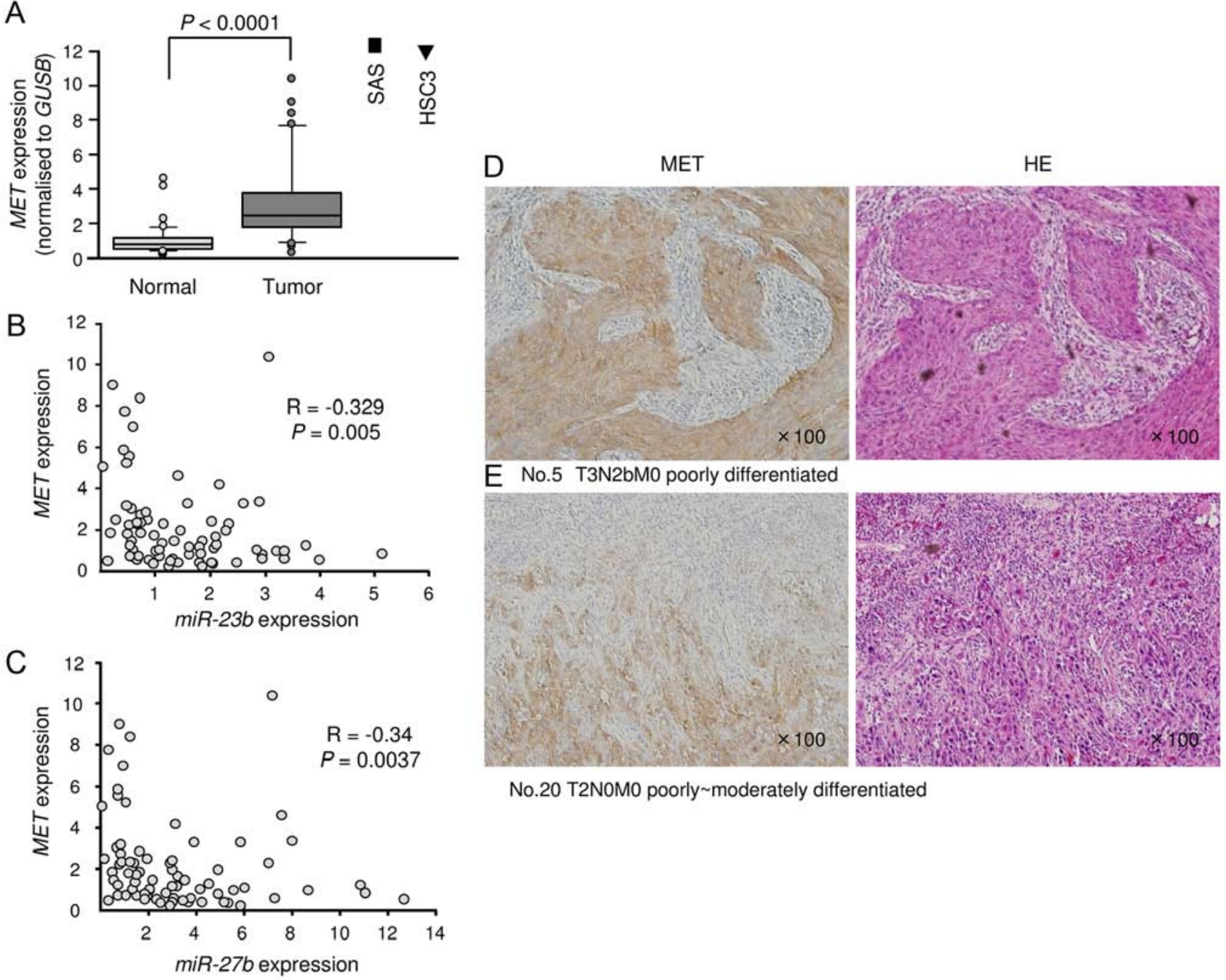

No.20 T2NOMO poorly moderately differentiated

Figure 4. Expression levels of MET in OSCC. (A) The mRNA expression levels of MET in OSCC clinical specimens and cell lines was measured. GUSB was used for the internal control. (B and C) Correlation between $M E T$ expression and $m i R-23 b$ (B) or $m i R-27 b$ (C). (D and E) Immunohistochemical staining for detection of MET and H\&E staining in two patients with OSCC.

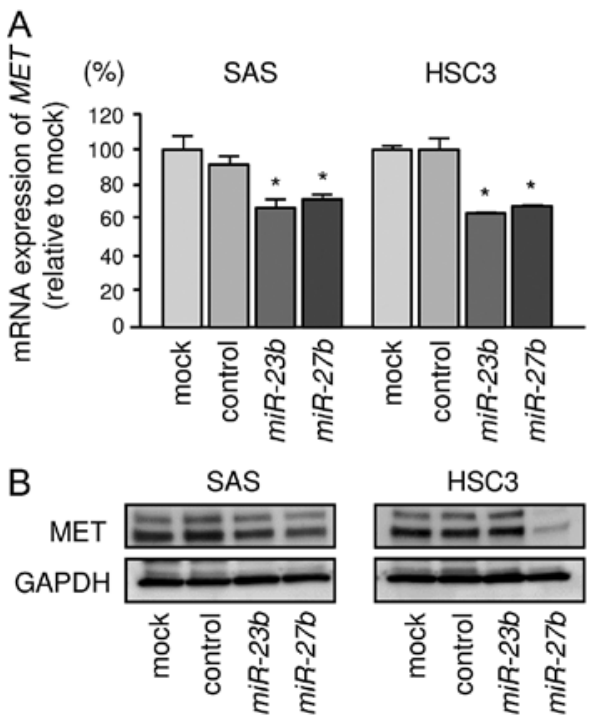

Figure 5. MET expression was directly regulated by $m i R-23 b / m i R-27 b$ in OSCC cell lines. (A) MET mRNA expression $72 \mathrm{~h}$ after transfection with $10 \mathrm{nM} m i R-23 b$ or $m i R-27 b$. GAPDH was used for the internal control. (B) MET protein expression $72 \mathrm{~h}$ after transfection with $10 \mathrm{nM} m i R-23 b$ or $m i R-27 b$. GAPDH was used for loading control. ${ }^{*} \mathrm{P}<0.001$ transfectant in HSC3 (Fig. 5B). Next, we performed luciferase reporter assays in OSCC cell lines to determine whether $M E T$ mRNA contained target sites for $m i R-23 b$ and $m i R-27 b$. We used vectors encoding either a partial wild-type sequence or a sequence in which the miRNA binding site had been mutated from the 3'-UTR of MET mRNA. Our data showed that the luminescence intensity was significantly reduced by co-transfection with $m i R-23 b / m i R-27 b$ and the vector carrying the wild-type 3'-UTR of MET mRNA (Fig. 6A and B).

Effect of silencing MET gene on cell proliferation, migration, and invasion in OSCC cells. To investigate the functional role of MET in OSCC, we performed loss-of-function studies using si-MET transfectants. First, we checked the knockdown efficiency of si-MET transfection. Western blotting and qRT-PCR revealed that the si-RNA effectively reduced the expression levels of MET in OSCC cell lines (Fig. 7A and B). Cell proliferation assays showed that SAS cell viability was significantly inhibited in si-RNA transfectants compared with mock or si-control. On the other hand, proliferation was not inhibited in HSC3 cells (Fig. 7C). Migration and invasion 
A
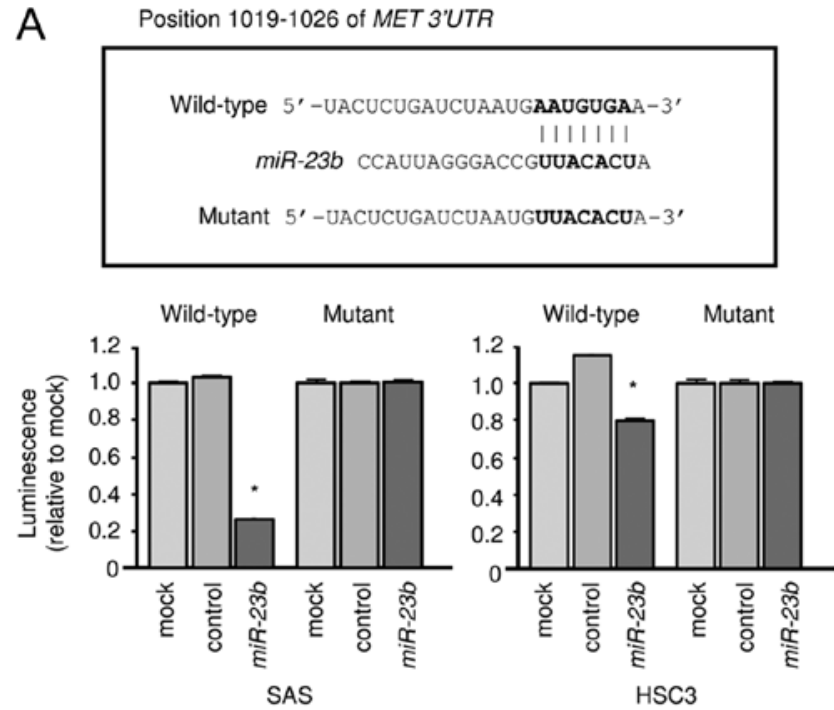

Position 2065-2072 of MET 3'UTR
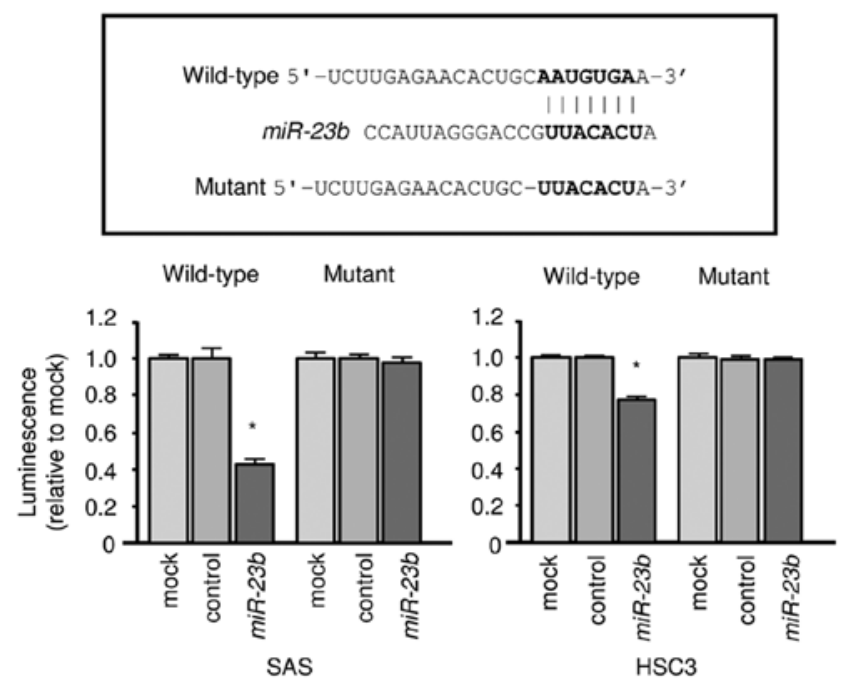

B

Position 1564-1571 of MET 3'UTR
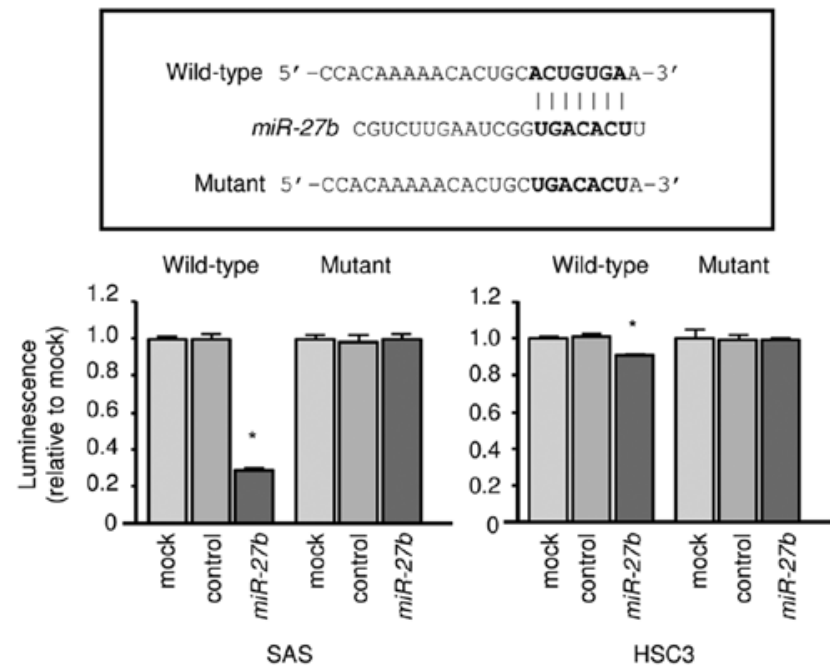

Figure 6. Luciferase reporter assays using OSCC cell lines. Luciferase reporter assays using the vectors encoding putative $m i R-23 b(\mathrm{~A})$ or $m i R-27 b(\mathrm{~B})$ target sites of the MET 3'-UTR for both wild-type and mutant co-transfectants. Renilla luciferase values were normalized to firefly luciferase values. ${ }^{*} \mathrm{P}<0.001$.

assays showed that cell migration activity was significantly inhibited in OSCC cells (Fig. 7D and E).

\section{Discussion}

A significant amount of evidence suggests that aberrantly expressed miRNAs are closely involved in human oncogenesis, metastasis and drug resistance (19). The cause of the poor prognosis of OSCC is distant metastasis of the cancer cells. Thus, identification of tumor-suppressive miRNAs that regulate novel metastatic pathways and metastasis-promoting genes may improve our understanding of OSCC progression and metastasis. We have sequentially identified tumor-suppressive miRNA-mediated novel cancer pathways in HNSCC and OSCC (18,20-24). We hypothesize that identification of novel metastatic pathways and targets regulated by tumor-suppressive miRNAs could lead to a better understanding of OSCC and the development of new therapeutic strategies to treat this disease.

Here, we focused on two clustered miRNAs, $m i R-23 b$ and $m i R-27 b$, based on miRNA expression signatures. Thus, we investigated the functional significance of these miRNAs in OSCC cells. We found that $m i R-23 b$ and $m i R-27 b$ were downregulated in cancer specimens and that restoration of $m i R-23 b$ and $m i R-27 b$ significantly inhibited cancer cell migration and invasion. These results strongly suggested that these miRNAs functioned as tumor suppressors in OSCC cells. Our previous studies of prostate cancer, renal cell carcinoma and bladder cancer showed that $m i R-23 b$ and $m i R-27 b$ act as tumor suppressors regulating several oncogenic genes (15-17). In renal cell carcinoma, significantly poor prognosis was observed in patients with lower expression levels of the $m i R-23 b / m i R-27 b$ cluster, suggesting that low expression of these miRNAs increased the risk of disease progression and predicted poor survival (18).

Other research groups have shown tumor-suppressive roles of $m i R-23 b$ and $m i R-27 b$ in several cancers (25-28). For example, $m i R-23 b$ directly controls the proto-oncogenes $S R C$ and $A K T$, and overexpression of $m i R-23 b$ suppresses cell viabilities, cell cycle arrest, and apoptosis (29). Another report has shown that $m i R-23 b$ and $m i R-27 b$ are downregulated in metastatic and castration-resistant prostate cancer (CRPC) tumors and that ectopic expression of these miRNAs suppresses cell invasion and migration in CRPC cell lines (30). Contrary to our data showing tumor suppressive roles of $m i R-23 b$ and $m i R-27 b$ in human cancers, expression levels of these miRNAs were significantly upregulated in human breast cancer, and $m i R-23 b$ and $m i R-27 b$ knockdown substantially represses breast cancer cell growth. These results indicate that these miRNAs function as oncogenes in this cellular context (31). Elucidation of the molecular mechanisms controlling expression of the $m i R-23 b / 27 b$ cluster is an important theme in this field.

Identification of miRNA-regulated pathways and targets is important to elucidate the molecular functions of tumorsuppressive $m i R-23 b$ and $m i R-27 b$ in OSCC cells. Towards that end, we combined expression data from OSCC clinical specimens and in silico miRNA database analysis. In this screening, several putative pathways and targets were annotated to be subject to $m i R-23 b$ and $m i R-27 b$ in OSCC cells. Among them, we focused on the $M E T$ oncogene because overexpression of $M E T$ was indicated by gene expression data and it is well known that MET activates signaling that contributes to cancer 
A

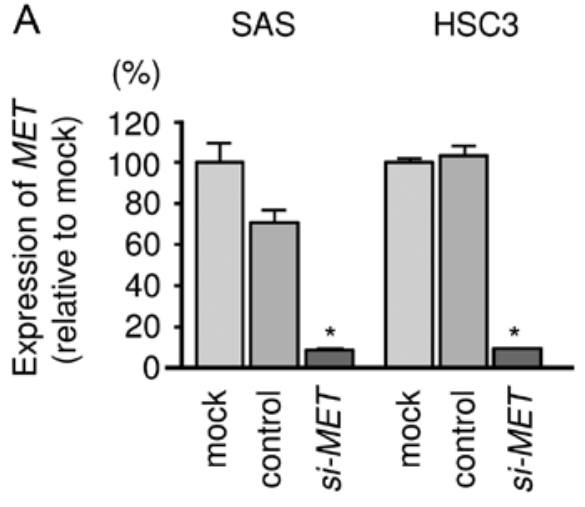

B

MET

SAS

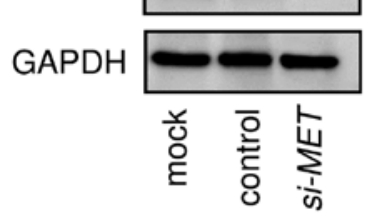

HSC3

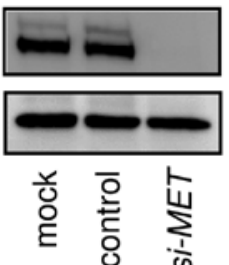

C

(\%)

SAS

HSC3

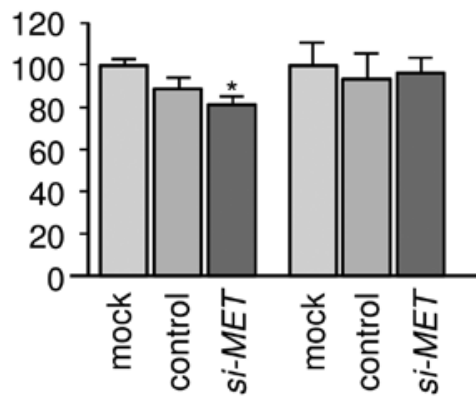

D

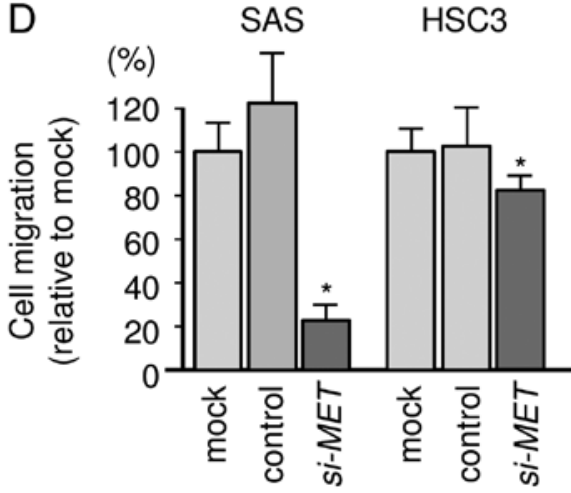

E

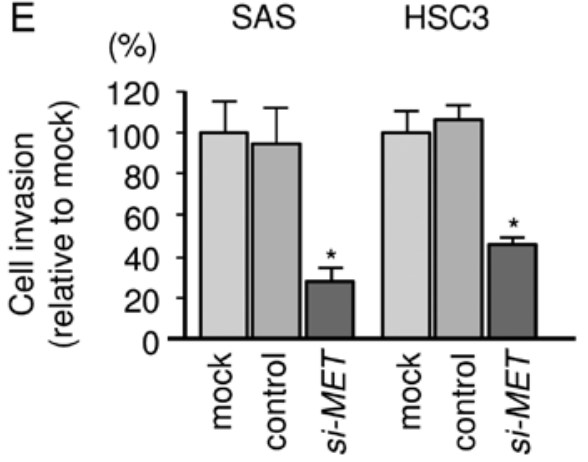

Figure 7. Effect of $M E T$ silencing by si-MET transfection of OSCC cell lines. (A) $M E T$ mRNA expression levels $72 \mathrm{~h}$ after transfection with $10 \mathrm{nM}$ si-MET. (B) MET protein expression levels $72 \mathrm{~h}$ after transfection with $10 \mathrm{nM}$ si-MET. (C-E) Effect of silencing of MET in OSCC cell lines. (C) Cell proliferation was determined with the XTT assay $72 \mathrm{~h}$ after transfection with $10 \mathrm{nM}$ si-MET. (D) Cell migration was assessed with the migration assay $48 \mathrm{~h}$ after transfection with $10 \mathrm{nM}$ si-MET. (E) Cell invasion was determined with the invasion assay $48 \mathrm{~h}$ after transfection with $10 \mathrm{nM}$ si-MET. $\mathrm{P}<0.05$.

cell proliferation, metastasis and drug resistance (32). One study reported that overexpression of $M E T$ was observed in $90 \%$ of HNSCC cell lines and $84 \%$ of HNSCC patient samples (33). Moreover, HGF overexpression has also been described in $\sim 60 \%$ of HNSCC, and co-expression of MET/HGF has been correlated with more aggressive disease behavior (33). Thus, the control of HGF/MET oncogenic signaling is the pivotal treatment target of the disease.

Cetuximab, a monoclonal antibody directed against the EGFR, is now available for targeted molecular therapy in HNSCC, including OSCC (34). Cetuximab is currently approved in combination with radiation therapy as a first-line treatment in combination with platinum and 5-fluorouracil in recurrent or metastatic disease $(35,36)$. However, the curative effects of these treatments are limited, and it is difficult to recover completely from this disease. Many studies have suggested different mechanisms that may be contributing to targeted EGFR resistance (37). A recent study showed that cetuximab-induced MET activation enhanced to cetuximabresistance in colon cancer cells (38). Aberrant MET expression and hepatocyte growth factor (HGF) signaling might be contributing as salvage pathways for EGFR blockade-resistant cancer cells. Therefore, dual blocking therapeutic strategies of EGFR and MET oncogenic signaling are indispensable for HNSCC and OSCC treatment.

In conclusion, $m i R-23 b$ and $m i R-27 b$ were frequently reduced in OSCC clinical specimens and appeared to act as tumor suppressors through targeting of the MET oncogene in this disease. Elucidation of novel target genes and pathways regulating by tumor-suppressive $m i R-23 b / 27 b$ cluster may provide new information of OSCC and the development of new treatment strategies of this disease. 


\section{Acknowledgements}

This study was supported by the KAKENHI(C), 15K10800, 15K10801, 25462676 and 26462596.

\section{References}

1. Min A, Zhu C, Peng S, Rajthala S, Costea DE and Sapkota D: MicroRNAs as important players and biomarkers in oral carcinogenesis. BioMed Res Int 2015: 186904, 2015.

2. Bhattacharya A, Roy R, Snijders AM, Hamilton G, Paquette J, Tokuyasu T, Bengtsson H, Jordan RC, Olshen AB, Pinkel D, et al: Two distinct routes to oral cancer differing in genome instability and risk for cervical node metastasis. Clin Cancer Res 17: 7024-7034, 2011

3. Liang L, Zhang T, Kong Q, Liang J and Liao G: A meta-analysis on selective versus comprehensive neck dissection in oral squamous cell carcinoma patients with clinically node-positive neck. Oral Oncol 51: 1076-1081, 2015.

4. Bartel DP: MicroRNAs: Genomics, biogenesis, mechanism, and function. Cell 116: 281-297, 2004.

5. Friedman RC, Farh KK, Burge CB and Bartel DP: Most mammalian mRNAs are conserved targets of microRNAs. Genome Res 19: 92-105, 2009.

6. Kikkawa N, Hanazawa T, Fujimura L, Nohata N, Suzuki H, Chazono H, Sakurai D, Horiguchi S, Okamoto Y and Seki N miR-489 is a tumour-suppressive miRNA target PTPN11 in hypopharyngeal squamous cell carcinoma (HSCC). Br J Cancer 103: 877-884, 2010

7. Nohata N, Hanazawa T, Kikkawa N, Sakurai D, Fujimura L, Chiyomaru T, Kawakami K, Yoshino H, Enokida H, Nakagawa M, et al: Tumour suppressive microRNA-874 regulates novel cancer networks in maxillary sinus squamous cell carcinoma. Br J Cancer 105: 833-841, 2011.

8. Fukumoto I, Kinoshita T, Hanazawa T, Kikkawa N, Chiyomaru T, Enokida H, Yamamoto N, Goto Y, Nishikawa R, Nakagawa M, et al: Identification of tumour suppressive microRNA-451a in hypopharyngeal squamous cell carcinoma based on microRNA expression signature. Br J Cancer 111: 386-394, 2014

9. Fukumoto I, Hanazawa T, Kinoshita T, Kikkawa N, Koshizuka K, Goto Y, Nishikawa R, Chiyomaru T, Enokida H, Nakagawa M, et al: MicroRNA expression signature of oral squamous cell carcinoma: Functional role of microRNA-26a/b in the modulation of novel cancer pathways. Br J Cancer 112: 891-900, 2015.

10. Nohata N, Hanazawa T, Kikkawa N, Mutallip M, Sakurai D, Fujimura L, Kawakami K, Chiyomaru T, Yoshino H, Enokida H, et al: Tumor suppressive microRNA-375 regulates oncogene AEG-1/MTDH in head and neck squamous cell carcinoma (HNSCC). J Hum Genet 56: 595-601, 2011.

11. Nohata N, Hanazawa T, Kinoshita T, Inamine A, Kikkawa N, Itesako T, Yoshino H, Enokida H, Nakagawa M, Okamoto Y et al: Tumour-suppressive microRNA-874 contributes to cell proliferation through targeting of histone deacetylase 1 in head and neck squamous cell carcinoma. Br J Cancer 108: 1648-1658, 2013.

12. Fuse M, Kojima S, Enokida H, Chiyomaru T, Yoshino $\mathrm{H}$ Nohata N, Kinoshita T, Sakamoto S, Naya Y, Nakagawa M, et al: Tumor suppressive microRNAs (miR-222 and miR-31) regulate molecular pathways based on microRNA expression signature in prostate cancer. J Hum Genet 57: 691-699, 2012.

13. Goto Y, Kojima S, Nishikawa R, Kurozumi A, Kato M, Enokida H, Matsushita R, Yamazaki K, Ishida Y, Nakagawa M, et al: MicroRNA expression signature of castration-resistant prostate cancer: The microRNA-221/222 cluster functions as a tumour suppressor and disease progression marker. Br J Cancer 113: 1055-1065, 2015

14. Itesako $\mathrm{T}$, Seki N, Yoshino $\mathrm{H}$, Chiyomaru $\mathrm{T}$, Yamasaki $\mathrm{T}$, Hidaka H, Yonezawa T, Nohata N, Kinoshita T, Nakagawa M, et al: The microRNA expression signature of bladder cancer by deep sequencing: The functional significance of the miR-195/497 cluster. PLoS One 9: e84311, 2014

15. Goto Y, Kojima S, Nishikawa R, Enokida H, Chiyomaru T, Kinoshita T, Nakagawa M, Naya Y, Ichikawa T and Seki N: The microRNA-23b/27b/24-1 cluster is a disease progression marker and tumor suppressor in prostate cancer. Oncotarget 5 : 7748-7759, 2014.
16. Chiyomaru $\mathrm{T}$, Seki $\mathrm{N}$, Inoguchi $\mathrm{S}$, Ishihara $\mathrm{T}$, Mataki $\mathrm{H}$, Matsushita R, Goto Y, Nishikawa R, Tatarano S, Itesako T, et al: Dual regulation of receptor tyrosine kinase genes EGFR and c-Met by the tumor-suppressive microRNA-23b/27b cluster in bladder cancer. Int J Oncol 46: 487-496, 2015.

17. Ishihara T, Seki N, Inoguchi S, Yoshino H, Tatarano S, Yamada $Y$, Itesako T, Goto Y, Nishikawa R, Nakagawa M, et al: Expression of the tumor suppressive miRNA-23b/27b cluster is a good prognostic marker in clear cell renal cell carcinoma. J Urol 192: $1822-1830,2014$

18. Kinoshita T, Nohata N, Hanazawa T, Kikkawa N, Yamamoto N, Yoshino H, Itesako T, Enokida H, Nakagawa M, Okamoto Y, et al: Tumour-suppressive microRNA-29s inhibit cancer cell migration and invasion by targeting laminin-integrin signalling in head and neck squamous cell carcinoma. Br J Cancer 109: 2636-2645, 2013.

19. Iorio MV and Croce CM: MicroRNAs in cancer: Small molecules with a huge impact. J Clin Oncol 27: 5848-5856, 2009.

20. Kinoshita T, Hanazawa T, Nohata N, Kikkawa N, Enokida H, Yoshino H, Yamasaki T, Hidaka H, Nakagawa M, Okamoto Y, et al: Tumor suppressive microRNA-218 inhibits cancer cell migration and invasion through targeting laminin-332 in head and neck squamous cell carcinoma. Oncotarget 3: 1386-1400, 2012.

21. Fukumoto I, Kikkawa N, Matsushita R, Kato M, Kurozumi A, Nishikawa R, Goto Y, Koshizuka K, Hanazawa T, Enokida H, et al: Tumor-suppressive microRNAs (miR-26a/b, miR-29a/b/c and miR-218) concertedly suppressed metastasis-promoting LOXL2 in head and neck squamous cell carcinoma. J Hum Genet 61: 109-118, 2016

22. Cano A, Santamaría PG and Moreno-Bueno G: LOXL2 in epithelial cell plasticity and tumor progression. Future Oncol 8: 1095-1108, 2012.

23. Peinado H, Moreno-Bueno G, Hardisson D, Pérez-Gómez E, Santos V, Mendiola M, de Diego JI, Nistal M, Quintanilla M, Portillo F, et al: Lysyl oxidase-like 2 as a new poor prognosis marker of squamous cell carcinomas. Cancer Res 68: 4541-4550, 2008.

24. Harisi R and Jeney A: Extracellular matrix as target for antitumor therapy. Onco Targets Ther 8: 1387-1398, 2015.

25. Huang TT, Ping YH, Wang AM, Ke CC, Fang WL, Huang KH, Lee HC, Chi CW and Yeh TS: The reciprocal regulation loop of Notch2 pathway and miR-23b in controlling gastric carcinogenesis. Oncotarget 6: 18012-18026, 2015.

26. Li W, Liu Z, Chen L, Zhou L and Yao Y: MicroRNA-23b is an independent prognostic marker and suppresses ovarian cancer progression by targeting runt-related transcription factor- 2 . FEBS Lett 588: 1608-1615,2014

27. Lee JJ, Drakaki A, Iliopoulos D and Struhl K: MiR-27b targets PPAR $\gamma$ to inhibit growth, tumor progression and the inflammatory response in neuroblastoma cells. Oncogene 31: 3818-3825, 2012.

28. Ye J, Wu X, Wu D, Wu P, Ni C, Zhang Z, Chen Z, Qiu F, Xu J and Huang J: miRNA-27b targets vascular endothelial growth factor $\mathrm{C}$ to inhibit tumor progression and angiogenesis in colorectal cancer. PLoS One 8: e60687, 2013.

29. Majid S, Dar AA, Saini S, Arora S, Shahryari V, Zaman MS, Chang I, Yamamura S, Tanaka Y, Deng G, et al: miR-23b represses proto-oncogene Src kinase and functions as methylation-silenced tumor suppressor with diagnostic and prognostic significance in prostate cancer. Cancer Res 72: 6435-6446, 2012.

30. Ishteiwy RA, Ward TM, Dykxhoorn DM and Burnstein KL: The microRNA -23b/-27b cluster suppresses the metastatic phenotype of castration-resistant prostate cancer cells. PLoS One 7: e52106, 2012.

31. Ell B, Qiu Q, Wei Y, Mercatali L, Ibrahim T, Amadori D and Kang Y: The microRNA-23b/27b/24 cluster promotes breast cancer lung metastasis by targeting metastasis-suppressive gene prosaposin. J Biol Chem 289: 21888-21895, 2014

32. Blumenschein GR Jr, Mills GB and Gonzalez-Angulo AM: Targeting the hepatocyte growth factor-cMET axis in cancer therapy. J Clin Oncol 30: 3287-3296, 2012.

33. Seiwert TY, Jagadeeswaran R, Faoro L, Janamanchi V, Nallasura V, El Dinali M, Yala S, Kanteti R, Cohen EE, Lingen MW, et al: The MET receptor tyrosine kinase is a potential novel therapeutic target for head and neck squamous cell carcinoma. Cancer Res 69: 3021-3031, 2009.

34. Sacco AG and Cohen EE: Current treatment options for recurrent or metastatic head and neck squamous cell carcinoma. J Clin Oncol 33: 3305-3313, 2015 . 
35. Bonner JA, Harari PM, Giralt J, Azarnia N, Shin DM, Cohen RB, Jones CU, Sur R, Raben D, Jassem J, et al: Radiotherapy plus cetuximab for squamous-cell carcinoma of the head and neck. N Engl J Med 354: 567-578, 2006.

36. Vermorken JB, Mesia R, Rivera F, Remenar E, Kawecki A, Rottey S, Erfan J, Zabolotnyy D, Kienzer HR, Cupissol D, et al: Platinum-based chemotherapy plus cetuximab in head and neck cancer. N Engl J Med 359: 1116-1127, 2008.
37. Bertotti A and Sassi F: Molecular pathways: Sensitivity and resistance to anti-EGFR antibodies. Clin Cancer Res 21: 3377-3383, 2015.

38. Song N, Liu S, Zhang J, Liu J, Xu L, Liu Y and Qu X: Cetuximabinduced MET activation acts as a novel resistance mechanism in colon cancer cells. Int J Mol Sci 15: 5838-5851, 2014. 